\title{
口蓋扁桃摘出術後の鼻咽腔閉鎖不全症例
}

\author{
森一功・川野 通夫 \\ 本庄嚴・藤村 英一*
}

\section{Velopharyngeal Insufficiency after Palatine Tonsillectomy; A Case Report}

\author{
Kazunori Mori, Michio Kawano and Iwao Honjo \\ (Kyoto University) \\ Eiichi Fujimura \\ (Kansai Electric Hospital)
}

A 51-year-old man developed velopharyngeal insufficiency after palatine tonsillectomy. His preoperative velopharyngeal function was normal and he had none of the features of Calnan's triad that suggest submucous cleft palate or congenital velopharyngeal insufficiency.

His velopharyngeal insufficiency was thought to be induced by adhesions between the lingual base and the anterior faucial pillars and cicatrication of the anterior faucial pillars. His velopharyngeal insufficiency was almost completely cured by resection of these scar tissues and covering the raw surface with a local buccal membrane flap.

Velopharyngeal insufficiency induced by palatine tonsillectomy is very rare, but it is a possible complication of palatine tonsillectomy and must be taken into account.

Key words: velopharyngeal insufficiency, palatine tonsillectomy, buccal flap

\section{緒言}

アデノイド切除が鼻咽腔閉鎖不全症を引き起 こすことは周知のことであるが，その頻度は扁 桃摘出を同時施行した場合は約 2000 人に 1 人1)2), アデノイド切除単独では 1500 人に 1 人 と報告されている1)。扁桃摘出術だけで鼻咽腔 閉鎖不全を来すことはさらに稀で，その報告は 少な(2) 4).

今回我々は口蓋扁桃摘出術後に鼻咽腔閉鎖不
全を来した症例を経験し，それに対して口蓋弓 の痗痕切離, 口蓋弓と舌根部の癒着の切離, 煩 部粘膜弁に上る被覆術を施行して, 注汪満足で きる結果を得たので報告する。

\section{症例}

患者：51歳, 男性.

主訴：両側扁桃摘出術後の開鼻声.

既往歴 : 術前, 鼻咽腔閉鎖不全症状はなし.

現病歴： 2 力月前他施設で局麻下に両側口蓋 
扁桃摘出術を受けた。術中扁桃の癒着がひどく， 止血のために左扁桃窝に才キシセルを詰めて前 後口蓋弓を縫合し，さらに術後右扁桃窩からの 出血に対し右前後口蓋弓も縫合したとのことで あった。術直後から飲食物の鼻腔への逆流と開 鼻声が生じている.

初診時所見：図 1 は初診時安静時の口腔内所 見で, 両側口蓋弓の瘵痕化, 舌根部之口蓋弓の 癒着が認められた。また, 硬口蓋の骨欠損や軟 口蓋の菲薄化, 口蓋垂裂など粘膜下口蓋裂を疑 わせる所見は認めなかった。図 2 は [a]発声 時の所見で, 軟口蓋の挙上が阻害されていた。

構音は開鼻声が著明であった。

検查成績: 図 3 は安静呼吸時, 図 4 は [a] 発声時の鼻咽腔内視鏡所見で, すべての構音で 鼻咽腔閉鎖不全を認め, 軟口蓋の運動性は既 報5)の判定基準で「不良」, 咽頭側壁の運動性

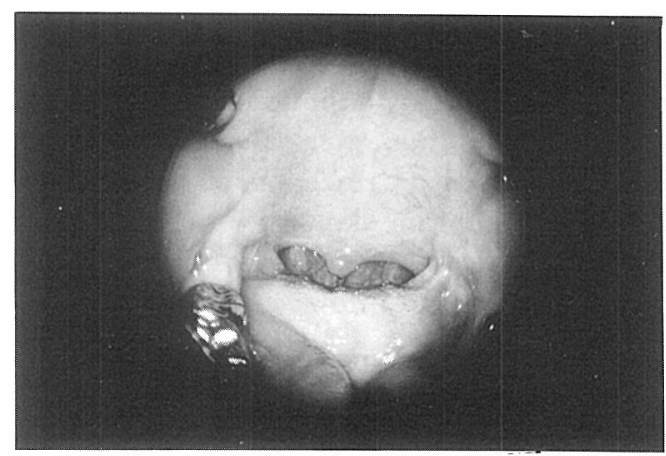

図 1 初診時口腔内所見

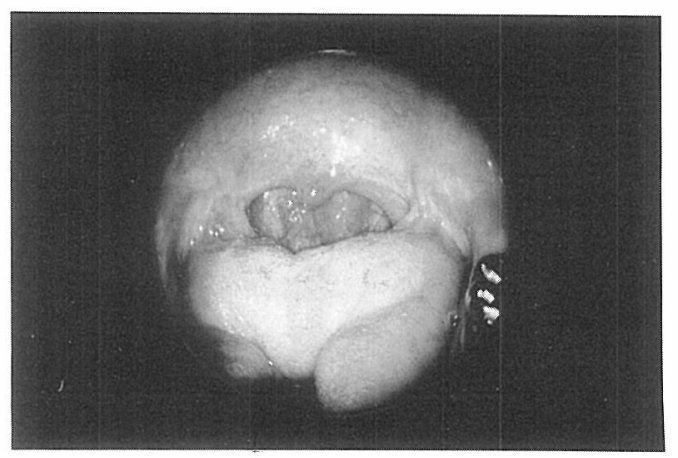

図 $2[\mathrm{a}]$ 発声時
は「やや不良」であった。鼻咽腔造影レ線ビデ オ検査でもすべての構音で鼻咽腔閉鎖不全があ り, 軟口蓋は挙上時「く」の字に変形するが, 後壁に接触せず，パッサーバン隆起がわずかに
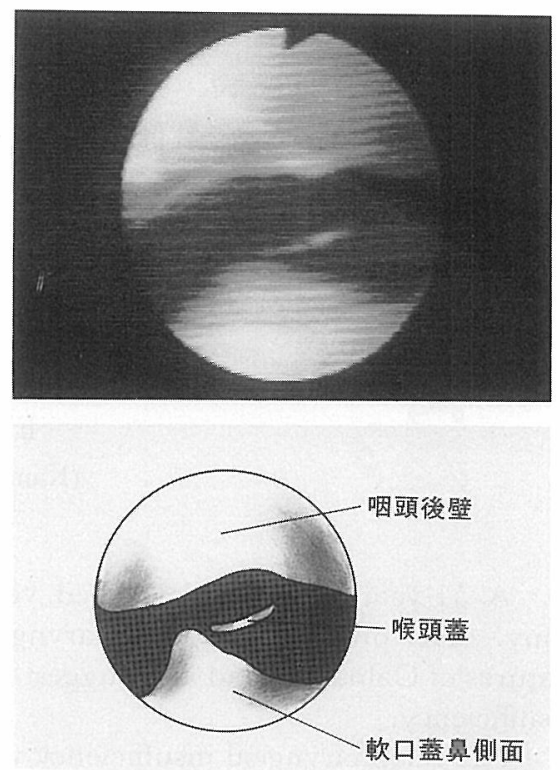

図 3 術前の安静呼吸時鼻咽腔内視鏡所見
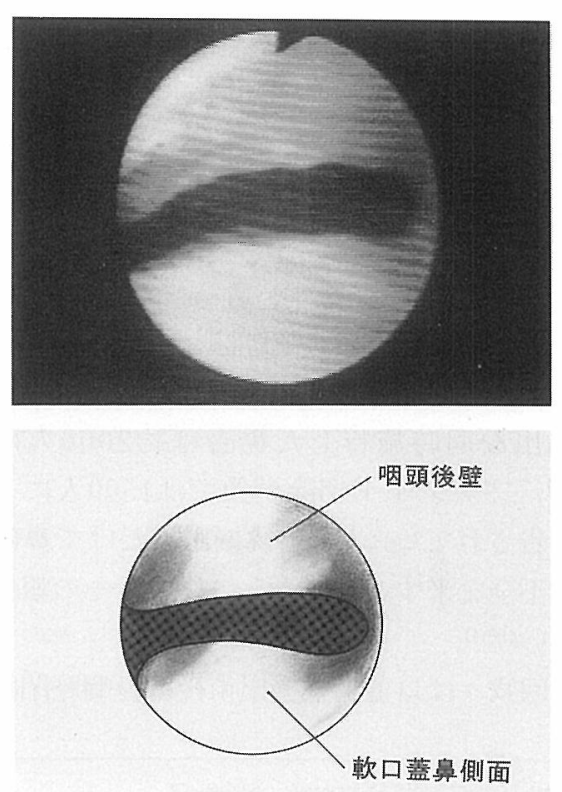

図 4 術前の $[\mathrm{a}]$ 発声時鼻咽腔内視鏡所見 
認められた(図 5 )。 また，既報5)にしたがって 咽頭腔の深さと軟口蓋の長さの比を測ると 1.12 で注淁正常範囲であった ${ }^{6)}$. 図 6 は [pa] 発声時 のニューモタコグラム所見で，鼻咽腔抵抗值を 計算すると, $22.4 \mathrm{dyn} \cdot \mathrm{sec} / \mathrm{cm}^{5}$ であった7). 以上をまとめると本症例では著明な鼻咽腔閉鎖 不全ありと判定された。

手術と経過：口蓋弓の瘷痕化と口蓋弓舌根部 の癒着とによる軟口蓋の挙上阻害が鼻咽腔閉鎖 不全の主因と考光られたので，全麻下に口蓋弓 舌根部の癒着の切離, 口蓋弓疫痕の切除, 拈よ び頓部粘膜弁による創部の被覆を行なった。

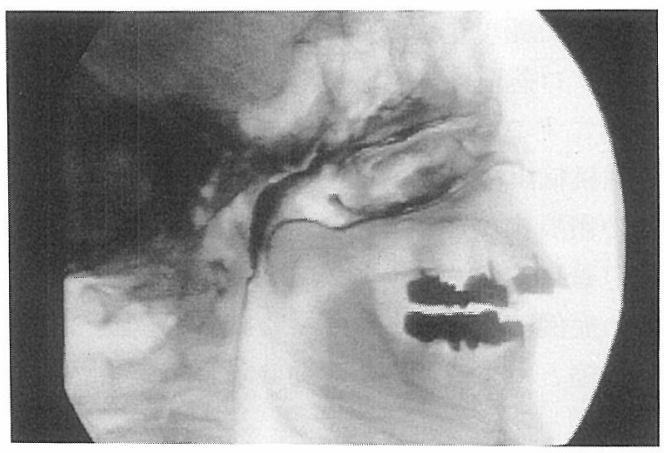

図 5 鼻咽腔レ線造影ビデオ所見
まず舌根部と口蓋弓との癒着部を切離し， ロ 蓋弓の瘢痕部分を切除して口蓋弓を延長した後, 図 7 のように切離部上端の口蓋に荨をもち, 先

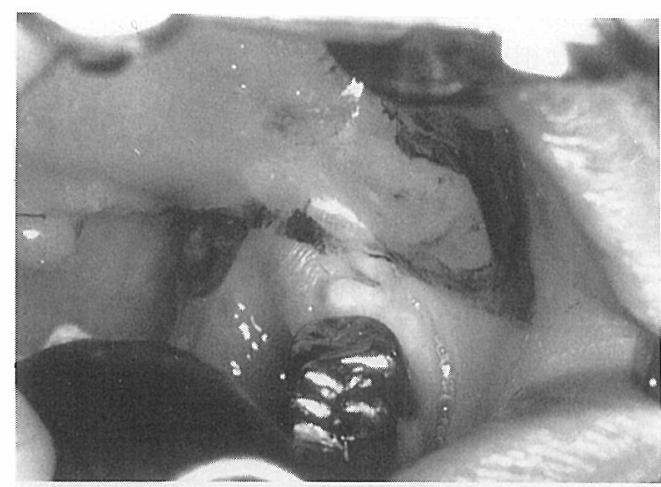

切離した 口蓋弓〜舌根の 痛着部

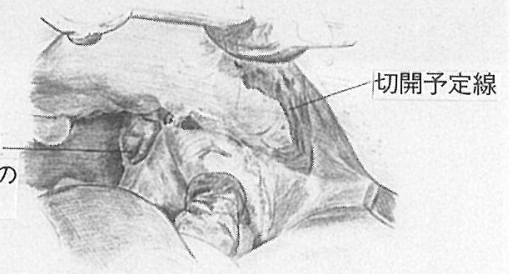

図 7 左頓部粘膜の切開線と, 左口蓋弓の癒着部 を切開したところ

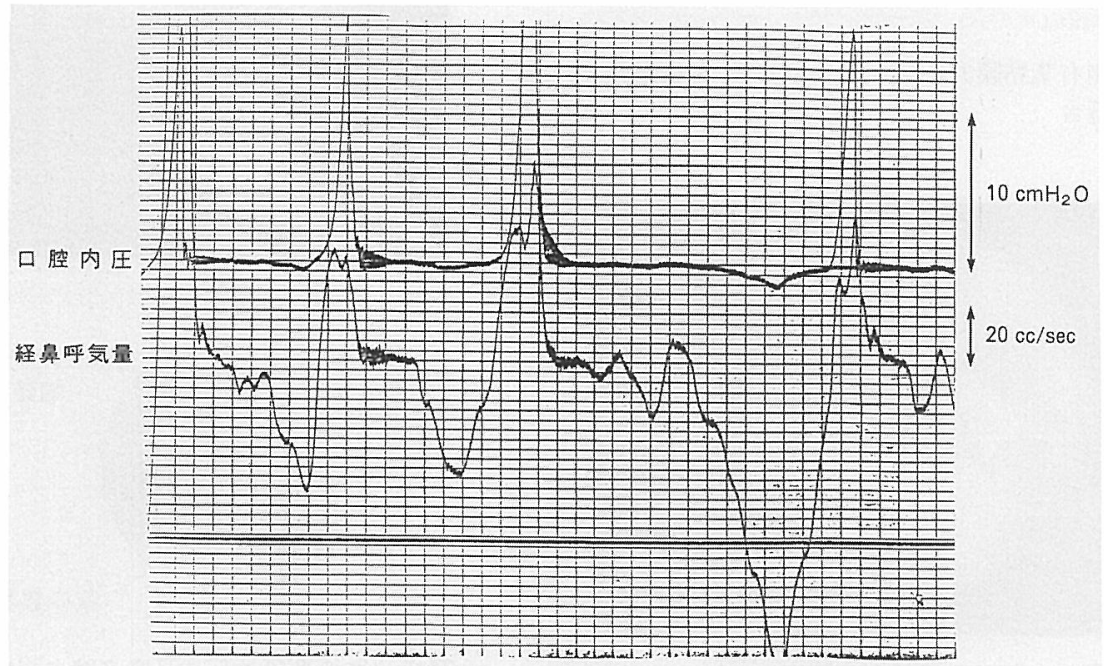

図 6 ニューモタコグラム所見 
端はステノン管の直下に及ぶ幅約 $1 \mathrm{~cm}$, 長さ $2.5 \mathrm{~cm}$ の有茎粘膜升を頓部粘膜から採取した. この弁を翻転して，口蓋弓切除部の raw-surface に縫合(図 8 ) した。

図 9 は術後 7 日目の口腔内所見で, 粘膜升部 は一部壊死に陥っているが術前に比べて口蓋弓
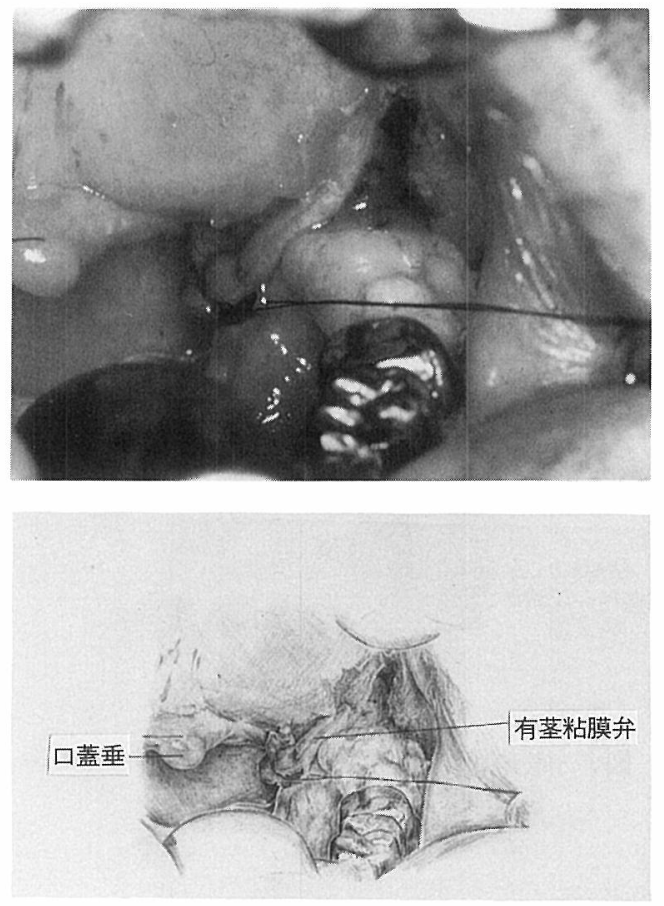

図 8 左側有菱粘膜升を翻転して, 口蓋弓切除部 旔合

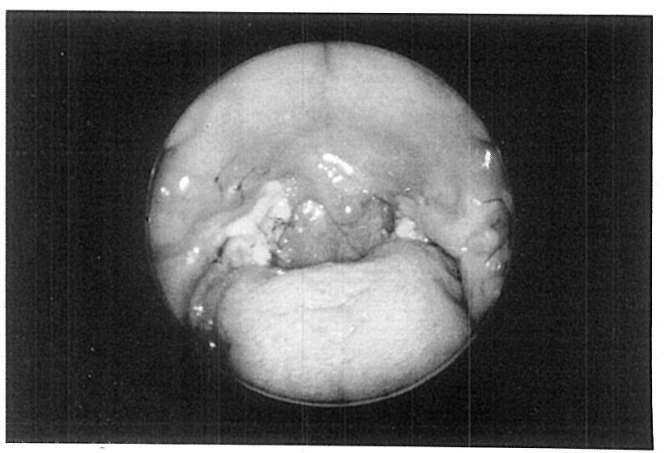

図 9 術後 7 日目の口腔内所見
は延長され，軟口蓋の運動性も良好である。さ らに術後半年では, 粘膜弁の部分がやや瘢痕拘 縮化し, 軟口蓋の運動を軽度阻害しているが, 汇湆良好な鼻咽腔閉鎖を得，構音は正常，軽度 の鼻雑音が残っている状態である。図10は術後 半年の [pa] 構音時の鼻咽腔内視鏡所見で，注 ぼ完全な鼻咽腔閉鎖が得られている。鼻咽腔抵 抗值は $78 \mathrm{dyn} \cdot \mathrm{sec} / \mathrm{cm}^{5}$ で，鼻咽腔閉鎖は生 活に支障のない程度に回復した。

\section{考按}

アデノイド切除後に鼻咽腔閉鎖不全が長期に 続〉場合，先天性鼻咽腔閉鎖不全症や粘膜下口 蓋裂などの潜在的な鼻咽腔閉鎖不全がアデノイ ド切除で顕現化することが考えられている28). 一方，口蓋扁桃摘出そのものが鼻咽腔閉鎖不全 を起こすことは疑問視されている9)。しかし口 蓋扁桃摘出に伴ら閉鎖不全の原因としては, 創 部の瘢痕拘縮が軟口蓋運動を阻害すること2), 軟口蓋自体の切除3)などが報告されている。今 回の症例は，舌縁と口蓋弓の癒着と口蓋弓の瘢 痕拘縮とによる軟口蓋運動の阻害が鼻咽腔閉鎖
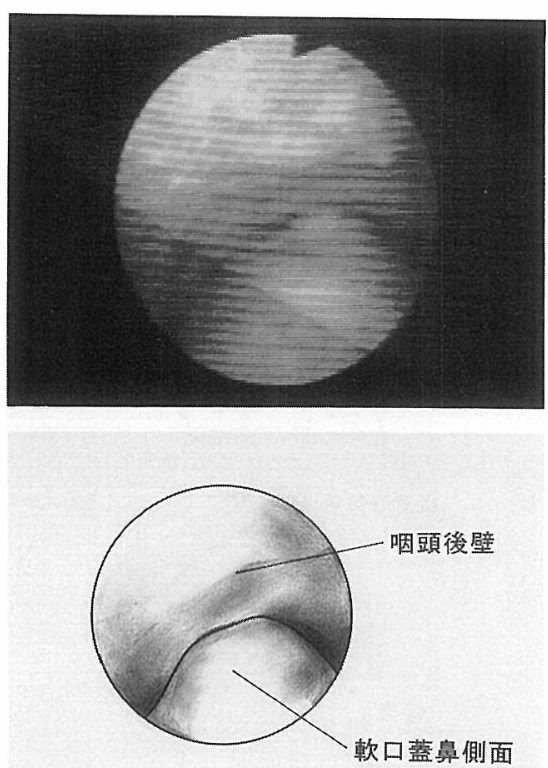

図10 術後半年の $[\mathrm{pa}]$ 構音時の鼻咽腔内視 鏡所見 
不全の原因と考えられた。

口蓋扁桃摘出後の㿂痕拘縮による鼻咽腔閉鎖 不全に対する治療法としては口蓋弓の瘢痕切除 と Z 形成術とが報告されている3に にすぎない。 本症例では口蓋弓の般痕化が著明で, 瘉着の切 離と痗痕切除だけでは再拘縮を起こすと判断し， 創部を頓粘膜弁で被覆して口蓋弓の延長を図っ た. 術後粘膜弁周囲の瘢痕拘縮が再度生じたが 鼻咽腔閉鎖不全はごく軽度とすることができた。

今回の経験から，口蓋扁桃摘出に执いても， 鼻咽腔閉鎖不全を来す可能性を念頭に置き, 術 後の誐痕拘縮を来さぬよら丁寧な摘出術を行な ら必要性があると考兄られた。

$$
\text { まとめ }
$$

口蓋扁桃摘出術により鼻咽腔閉鎖不全を来し た症例に，口蓋弓の冹痕拘縮切除々頓粘膜有茎 弁での被覆とで，核良好な結果を得た。扁桃 摘出に際し, 鼻咽腔閉鎖不全を来す可能性を念 頭に置く必要性を述べた。

\section{文献}

1) Van Gelder L : On open nasal speech following adenoidectomy and tonsillectomy. Pract OtoRhino-Laryng 29 : 129 140, 1967.
2) Gibb AG : Hypernasality (rhinolalia aperta) following tonsil and adenoid removal. J Laryngol Otol $72: 433 \sim 451,1958$.

3) Crikelair GF, Kastein S, Fowler EP, et al : Velar dysfunction in the absence of cleft palate. NY J Med 15 : 263 269, 1964.

4) Gibb AG and Stewart IA : Hypernasality following tonsil dissection. J Laryngol Otol $89:$ :779 781, 1975.

5）川野通夫：鼻咽腔閉鎖軽度不全例の考察. 日口 蓋誌 $14: 2 ； 285,1989$.

6）東 文生：構音機構の年齢的発達に関寸る研究. 耳鼻臨床 59 : 105 132, 1966.

7）本庄 撖, 一色信彦：鼻咽腔閉鎖機能の診断法. 耳鼻臨床 $64: 853 \sim 861,1971$.

8) Roberts WJ : Speech defects following adenotonsillectomy. Rocky Mountain Med J 55 : 67 $\sim 69,1959$.

9) Clanan JS : Investigation of children with speech defects; with particular reference to nasality. Br Med J $1: 737 \sim 740,1958$.

$$
\left(\begin{array}{l}
\text { 原稿受付 : 平成 } 2 \text { 年 } 12 \text { 月 } 26 \text { 日 } \\
\text { 原稿採択 : 平成 } 3 \text { 年 } 1 \text { 月 } 26 \text { 日 } \\
\text { 別刷請求先 : 川野通夫 } \\
\text { 干606 京都市左京区聖護院川原町 } 54 \\
\text { 京都大学医学部耳鼻咽喉科学教室 }
\end{array}\right)
$$

